\title{
Potential Zoonotic Faecal Bacteria from Sunda Porcupine (Hystrix javanica) and Their Antimicrobial Resistance Profiles
}

\author{
SARSA A. NISA ${ }^{1}$, RIFKA A. N. SAFITRI ${ }^{1}$, NURUL INAYAH ${ }^{2}$, ACHIRUL NDITASARI $^{3}$, SUSIANA \\ PURWANTISARI $^{1}$, REJEKI S. FERNIAH ${ }^{1}$, ANANG S. ACHMADI ${ }^{2}$, TAUFIQ P. NUGRAHA ${ }^{2}$, AND \\ SUGIYONO SAPUTRA ${ }^{3 *}$
}

\author{
${ }^{\prime}$ Department of Biology, Faculty of Sains and Mathematics, Diponegoro University, \\ Jalan Prof. Sudarto No.13, Tembalang, Semarang 50275, Indonesia; \\ ${ }^{2}$ Museum Zoologicum Bogoriense, Research Center for Biology, Indonesian Institute of Sciences, \\ Jalan Raya Jakarta-Bogor Km 46, Cibinong 16911, Indonesia; \\ ${ }^{3}$ Microbiology Division, Research Center for Biology, Indonesian Institute of Sciences, \\ Jalan Raya Jakarta-Bogor Km 46, Cibinong 16911, Indonesia.
}

\begin{abstract}
Sunda porcupine (Hystrix javanica) is one of the Indonesian endemic species which is often sought after for their meat. Although it is becoming increasingly popular for extreme culinary, information regarding biological risks arising from this wildlife is very limited. This study aimed to assess potential zoonotic faecal bacteria carried by Sunda porcupine and to investigate their antimicrobial resistance (AMR) profile. A total 22 faecal samples were collected from captive Sunda porcupine and subjected to presumptive test for Salmonella and Listeria. Two samples $(9 \%)$ were regarded as positive for Salmonella which was indicated by the presence of black colonies on xylose lysine deoxycholate (XLD) agar. Meanwhile, the presence for Listeria was positive in all samples (100\%), indicated by colour change in medium from straw to black in Listeria Isolation Transwab®. In total, 36 bacterial colonies were isolated and subjected for antimicrobial susceptibility testing (AST) by disk diffusion method. Most importantly, multidrug-resistant bacteria and resistance to third generation cephalosporins (ceftriaxone) were not observed, indicating low risk of AMR dissemination. Based on 16S rRNA gene analysis and phylogenetic tree construction from selected isolates, we identified several potential food-borne zoonotic pathogens, including Proteus mirabilis (XH3.3, H4.2, and E1.2), Shigella flexneri (XD8.2 and G11.3), and Klebsiella quasipneumoniae subsp. similipneumoniae (XF4.2). Further research to confirm the pathogenicity of those isolates is still needed but based on these results, we support the hypothesis that Sunda porcupine is potential as a reservoir of pathogenic bacteria. Preventive measures are crucial to prevent transmission when processing this bushmeat.
\end{abstract}

Key words: 16S rRNA, antimicrobial resistance, Sunda porcupine, zoonoses

Landak Jawa (Hystrix javanica) merupakan salah satu spesies endemik Indonesia yang sering dimanfaatkan dagingnya. Meski semakin populer untuk kuliner ekstrem, informasi mengenai risiko biologis yang timbul dari satwa liar ini masih sangat terbatas. Penelitian ini bertujuan untuk mengkaji bakteri potensial penyebab zoonosis yang dibawa oleh landak Jawa dan untuk mengetahui profil antimicrobial resistance (AMR) pada isolat yang didapatkan. Sebanyak 22 sampel feses diambil dari landak Jawa disertakan untuk uji presumtif Salmonella dan Listeria. Dua sampel (9\%) dinyatakan positif Salmonella yang ditunjukkan dengan adanya pertumbuhan koloni hitam pada xylose lysine deoxycholate (XLD) agar. Sementara itu, keberadaan Listeria dinyatakan positif pada semua sampel (100\%), ditunjukkan dengan munculnya warna hitam pada media Listeria Isolation Transwab ${ }^{\circ}$. Secara total, 36 koloni bakteri berhasil diisolasi dan diuji resistensinya menggunakan metode difusi cakram. Bakteri multidrug-resistant dan resistensi terhadap generasi ketiga sefalosporin (ceftriaxone) tidak terdeteksi yang mengindikasikan resiko rendah penyebaran AMR. Berdasarkan analisis gen 16S rRNA dan konstruksi pohon filogenetik isolat terpilih, kami mengidentifikasi beberapa bakteri yang potensial sebagai food-borne zoonotic pathogens, diantaranya Proteus mirabilis (XH3.3, H4.2, dan E1.2), Shigella flexneri (XD8.2 dan G11.3) dan Klebsiella quasipneumoniae subsp. similipneumoniae (XF4.2). Penelitian lebih lanjut untuk mengkonfirmasi patogenisitas isolat masih diperlukan tetapi berdasarkan hasil ini, kami mendukung hipotesis bahwa landak Jawa berpotensi sebagai reservoir bakteri patogen. Tindakan pencegahan sangat penting dilakukan untuk mencegah penularan terutama pada saat memproses daging hewan liar ini.

Kata kunci: 16S rRNA, antimicrobial resistance, landak Jawa, zoonosis

Bushmeat hunting and wildlife trade for consumption are contributing factors to zoonotic

*Corresponding author: Phone: +62-21-87907604; Fax: +6221-87907612; E-mail: sugiyono.saputra@lipi.go.id disease transmission. The existence of wild animals that should be in nature and far from human life, now carried in the form of exotic food and medicine, which can accelerate the transmission of zoonotic diseases (Broad 2020). The spillover events occur due to human-animal 
interactions during hunting, carrying, storing, raising, selling, killing, and consuming wild animals (Plotkin 2020). This unsustainable wildlife hunting practices mainly operated in Asia, Africa and South America, leading to a significant extinction threat to several wild terrestrial mammals(Ripple et al. 2016).

Bushmeat from wild mammals, has been used for consumption in Indonesia for decades. One of the wild mammals that is becoming more popular for consumption is Sunda porcupine (Hystrix javanica) which is an endemic Indonesian wildlife that belongs to the Rodentia order (Lunde and Aplin 2008). The distribution region of these animals includes Sumatra, Kalimantan, Java, and Bali (Lunde and Aplin 2008). Sunda porcupine have spines as their defence system (Myers et al. 2017), nocturnal and herbivorous as in their natural habitat, they eat plant parts such as tubers, bamboo shoots, seeds, fruit, tubers, rhizomes, young shoots, and bark (Farida 2015). Sunda porcupine meat have long been consumed as a source of protein for extreme culinary. They believe that consuming porcupine meat is preventing from osteoporosis and improving body vitality, while the liver and bile can cure asthma, and the thorns can be used to treat toothaches and ulcers (Farida 2007; Farida 2015; Wardi et al. 2011).

The international conservation status based on the IUCN Red List of Threatened Species classified Sunda porcupine to least concern or not threatened. In Indonesia, this wildlife is protected under the Regulation of the Minister of Environment and Forestry of the Republic of Indonesia Number: P.106/MENLHK/SETJEN/KUM.1/12/2018. Despite they have protected status, illegal hunting and trade of Sunda porcupine are still rampant (Inayah 2016). Additionally, biological risk information including transmission of zoonoses and antimicrobial resistance that may result from the hunting and trade this wild animal is not well recorded. In this preliminary study, we aimed to assess potential zoonotic bacteria arising from Sunda porcupine faecal samples by culturedependent approach. Faeces and intestinal contents are often contaminated the meat during slaughtering and processing activities. The presence of antimicrobial resistance will also be investigated by characterizing their phenotypic resistance to several antimicrobial categories. This assessment will be useful for prevention measures for tackling emerging and reemerging infectious diseases from wildlife.

\section{MATERIALS AND METHODS}

Animals and Sampling. Sampling was conducted at the small mammal research facility in Research Center for Biology, Indonesian Institute of Sciences. A total 22 Sunda porcupine (aged 2-3 years) were used as the object of study. Prior sampling, Sunda porcupine had no receive any special medical treatment for the last three months with usual diet include leaves and tubers. Sampling was performed using non-invasive methods without making direct contact to each individual by swabbing fresh faecal samples in the morning and transfer directly into RappaportVassiliadis (RV) Salmonella enrichment broth (Himedia, India) and Listeria Isolation Transwab ${ }^{\circledR}$ (Medical Wire, UK) for the bacterial enrichment stage (Kartika et al. 2017). This procedure has been approved by animal ethics commission, Indonesian Institute of Sciences (B-12220/IPH/KS.02.04/IPH/IX/2019).

Presumptive Test and Bacterial Isolation. Presumptive test for Salmonella and Listeria were selected in this study because these bacteria widely known as foodborne pathogens and contaminant of animal products. After inoculating faecal samples, RV Salmonella enrichment broth was incubated at $42^{\circ} \mathrm{C}$ for 24 hours, followed by subsequent inoculation to xylose lysine deoxycholate (XLD) agar (Himedia, India). XLD agar is a selective medium that primarily used for isolation and differentiation of Salmonella and Shigella. Shigella colonies maybe difficult to differentiate with other Gram-nagative bacteria, thus presumptive test was not performed. In the other hand, typical colony growth with black spot in the center on XLD agar media is easy to observe, indicating the presence of Salmonella. Meanwhile, Listeria Isolation Transwab ${ }^{\circledR}$ is used for the detection of Listeria. After incubation at $37^{\circ} \mathrm{C}$ for 24 hours color change from straw to black is an indication the growth of Listeria spp. in the sample and the results were regarded as positive. The isolation process was continued by using Columbia agar supplemented with dehydrated horse blood (5\%) to detect hemolysis activity. A clear zone that appears below or around the colonies indicate beta hemolytic activity. Preservation of isolates were conducted using Mueller Hinton Broth media added with $20 \%$ glycerol and then stored at $-80^{\circ} \mathrm{C}$. Salmonella enterica subsp. enterica JCM 1652 and Listeria monocytogenes JCM 7671 were used as positive controls during the isolation process. 
Antimicrobial Susceptibility Testing. Antimicrobial susceptibility testing was performed using the disk diffusion method based on protocol from the European Committee on Antimicrobial Susceptibility Testing (EUCAST) (EUCAST 2020). Mueller Hinton Agar (MHA) was used by inoculating bacterial inoculum with turbidity standard of 0.5 McFarland or equivalent to $1.5 \times 108 \mathrm{CFU} / \mathrm{mL}$. Antimicrobial disc (Oxoid, USA) used in this study include $30 \mu \mathrm{g}$ each of amikacin (AK, aminoglycosides), amoxicillin-clavulanic acid (AMC, penicillin-beta lactamase inhibitors), cefoxitin (FOX, second generation cephalosporins) ceftriaxone (CRO, third generation of cephalosporins). The inhibition zone diameter (IZD) in agar media was indicated by the formation of a clear zone around the antibiotic disc. Interpretation of IZD results is species-specific and antimicrobial-specific, however, in order to describe potentially resistant isolates, we interpreted IZD results (resistant, intermediate or sensitive) using breakpoints for Enterobacterales according to European Committee on Antimicrobial Susceptibility Testing (EUCAST) guideline and zone diameter interpretive standards breakpoints for veterinary pathogens according to Clinical \& Laboratory Standards Institute (CLSI, 2015). We then categorised resistance cut off for amoxicillin-clavulanic acid and amikacin when with IZD $\leq 14 \mathrm{~cm}$ while for cefoxitin and ceftriaxone when IZD $\leq 17 \mathrm{~cm}$. Multidrugresistant bacteria are defined when bacterial isolates have resistance to one agent in three or more antimicrobial categories (CLSI 2015). Escherichia coli ATCC 25922 and Staphylococcus aureus ATCC 25923 were used as control bacteria.

Molecular Identification Based on the 16S rRNA. Extraction of bacterial DNA using Chelex ${ }^{\circledR}$ 100 sodium form $10 \%$ (Sigma Aldrich) according to the protocol from Saputra et al. (2017). Amplification of the 16S rRNA gene was performed on a Veriti TM 96Well Fast Thermal Cycler (Applied Biosystems, USA) using Bioline MyTaq TM Red Mix (Meridian Bioscience) using universal primer 27F and 1492R. PCR products were subjected to Sanger dideoxy sequencing (1st BASE, Singapore). The DNA sequences obtained using primer $27 \mathrm{~F}$ were analyzed using the MEGA X program and alignment of the bases sequences were performed on GenBank ${ }^{\circledR}$ DNA using the Basic Local Alignment Search Tool (BLAST) menu. Phylogenetic tree construction was made by neighbor joining method with 1000 bootsrap value.

\section{RESULTS}

\section{Presumptive Test for Salmonella and Listeria.} Presumptive test for Salmonella on XLD agar showed that 2 out of 22 samples tested positive (F2 and H3), which was indicated by the growth of typical black or black spots colonies. A total of 18 bacterial isolates were successfully purified and preserved. For Listeria presumptive test, all samples $(100 \%)$ were regarded positive which was indicated by color change in the Listeria Isolation Transwab ${ }^{\circledR}$ from straw to black. A total of 18 isolates were successfully purified and preserved, with four isolates showing hemolytic activity (E5.1, G8.2, G11.1, and G11.3) in Columbia agar supplemented with $5 \%$ dehydrated horse blood. Presumptive tests and all isolates collected in this study are presented in Table 1 .

Distribution of Inhibition Zone Diameter (IZD). Antimicrobial susceptibility testing showed that only one isolate that showing no inhibition zone diameter (XG10.1) and regarded as cefoxitin resistant strain. Four isolates with inhibition zone diameter $<10$ was observed. Resistance to third generation of cephalosporins (ceftriaxone) was not detected. The distribution of all isolates with the inhibition zone diameter against four antimicrobials can be seen in Figure 1. Interpreted according to IZD breakpoint from EUCAST and CLSI, only two isolates that showed resistance to two antimicrobials tested (AMC and FOX), while five isolate showed resistance to one antimicrobials (AK or FOX). Resistance to all antimicrobial (multidrug-resistant bacteria) tested in this study was not observed. The resistance profile of the seven bacterial isolates from the Sunda porcupine are presented in Table 1.

Identified Bacteria and Their Susceptibility against Antibiotics. Seven bacterial isolates were selected based on colony appearance for bacterial identification using 16S rRNA gene. At least $~ 700-800$ bp of nucleotides were generated for BLAST analysis in GenBank ${ }^{\circledR}$. Percentage of identity of those isolates can be seen in Table 2 which also include inhibition zone diameter results. All seven isolates were sensitive to amikacin, amoxicillin-clavulanic acid, cefoxitin and ceftriaxone, except for Shigella flexneri (XD8.2) which was resistant to cefoxitin. The phylogenetic tree constructions of seven isolates compared with reference strains are presented in Figure 2. 
Table 1. Presumptive test results and resistance profile of isolated bacteria from 22 faecal samples

\begin{tabular}{|c|c|c|c|c|c|c|}
\hline $\begin{array}{l}\text { Sample } \\
\text { ID }\end{array}$ & $\begin{array}{c}\text { Presumptive } \\
\text { Salmonella }\end{array}$ & $\begin{array}{l}\text { Presumptive } \\
\text { Listeria }\end{array}$ & $\begin{array}{l}\text { Isolate } \\
\text { code }\end{array}$ & $\begin{array}{l}\text { Hemolysis } \\
\text { activity }\end{array}$ & Colony appearance & $\begin{array}{l}\text { Resistance } \\
\text { profile }\end{array}$ \\
\hline \multirow[t]{2}{*}{ D6 } & - & + & XD6.2 & & milky white & - \\
\hline & & & XD6.3 & & yellow & - \\
\hline D7 & - & + & - & - & - & - \\
\hline \multirow[t]{2}{*}{ D8 } & - & + & D8.1 & - & white & - \\
\hline & & & XD8.2 & & white & FOX \\
\hline E1 & - & + & E1.2 & - & milky white & - \\
\hline $\mathbf{E} 4$ & - & + & XE4.2 & & yellow & - \\
\hline \multirow[t]{2}{*}{ E5 } & - & + & E5.1 & + & $\begin{array}{l}\text { transparent white, clear } \\
\text { zone }\end{array}$ & $\mathrm{AK}$ \\
\hline & & & XE5.1 & & yellow & - \\
\hline \multirow[t]{2}{*}{ E6 } & - & + & E6.3 & - & white & - \\
\hline & & & XE6.2 & & yellow & - \\
\hline E7 & - & + & E7.1 & - & transparent white & - \\
\hline E8 & - & + & E8.1 & - & milky white & $\mathrm{AK}$ \\
\hline F1 & - & + & - & - & - & - \\
\hline \multirow[t]{2}{*}{ F2 } & + & + & F2.2 & - & white & - \\
\hline & & & $\mathrm{XF} 2.2$ & & white & - \\
\hline \multirow[t]{2}{*}{$\mathbf{F 4}$} & - & + & F4.2 & - & milky white & - \\
\hline & & & $\mathrm{XF} 4.2$ & & yellowish black & - \\
\hline \multirow[t]{3}{*}{ G4 } & - & + & G4.1 & - & transparent white & $\mathrm{AMC}, \mathrm{FOX}$ \\
\hline & & & XG4.4 & & white & - \\
\hline & & & XG4.5 & & yellowish white & - \\
\hline G5 & - & + & - & - & - & - \\
\hline \multirow[t]{2}{*}{ G8 } & - & + & G8.2 & + & $\begin{array}{l}\text { yellowish white, clear } \\
\text { zone }\end{array}$ & - \\
\hline & & & $\mathrm{XG} 8.2$ & & yellow & - \\
\hline G9 & - & + & XG9.3 & & white & - \\
\hline \multirow[t]{3}{*}{ G10 } & - & + & G10.1 & - & transparent white & $\mathrm{AK}$ \\
\hline & & & G10.2 & - & white & $\mathrm{AK}$ \\
\hline & & & $\mathrm{XG} 10.1$ & & yellow & $\mathrm{AMC}, \mathrm{FOX}$ \\
\hline \multirow[t]{3}{*}{ G11 } & - & + & G11.1 & + & milky white, clear zone & - \\
\hline & & & G11.2 & - & transparent white & - \\
\hline & & & G11.3 & + & white, clear zone & - \\
\hline \multirow[t]{2}{*}{ H1 } & - & + & $\mathrm{H} 1.3$ & - & white & - \\
\hline & & & $\mathrm{XH} 1.2$ & & yellowish white & - \\
\hline $\mathbf{H 2}$ & - & + & $\mathrm{XH} 2.3$ & & white & - \\
\hline \multirow[t]{3}{*}{ H3 } & + & + & $\mathrm{H} 3.3$ & - & transparent white, & - \\
\hline & & & $\mathrm{XH} 3.2$ & & black spot & - \\
\hline & & & XH3.3 & & black & - \\
\hline \multirow[t]{2}{*}{ H4 } & - & + & $\mathrm{H} 4.2$ & - & white & - \\
\hline & & & XH4.1 & & white & \\
\hline
\end{tabular}

Note: AK amikacin, AMC amoxicillin-clavulanic acid, FOX cefoxitin.

\section{DISCUSSION}

To the best of our knowledge, this is the first study in Indonesia to assess potential zoonoses from faecal samples of Sunda porcupine. This preliminary study has three main findings: 1) proportion of presumptive test for Salmonella and Listeria which regarded as positive were $9 \%(2 / 22)$ and $100 \%(22 / 22)$, respectively; 2) several potential zoonotic pathogens was observed, including Proteus mirabilis $(\mathrm{n}=3)$, Shigella flexneri $(\mathrm{n}=2)$ and Klebsiella quasipneumoniae subsp. similipneumoniae $(\mathrm{n}=1)$; and 3) multidrug-resistant bacteria and resistance to the latest generation antimicrobial used in this study (ceftriaxone) was not detected.

Porcupine is one of the popular bushmeat not only in Southeast Asian countries (Engel and Ziegler 2020) but also in several African countries (Bachand et al. 2012, Friant et al. 2015). Brush-tailed porcupine (Atherurus africanus) is the most preferred animal for their meat in Nigeria and consumed regularly up to once per week (Friant et al. 2015). The activities related to this bushmeat consumption which include hunting, trade, and meat processing has led to a higher risk of zoonotic bacteria transmission (Plotkin 2020). It is reported that Salmonella were observed on the dorsal skin of Sunda porcupine ( Prawira et al. 2018) and carcass of Brush-tailed porcupine (Bachand et al. 

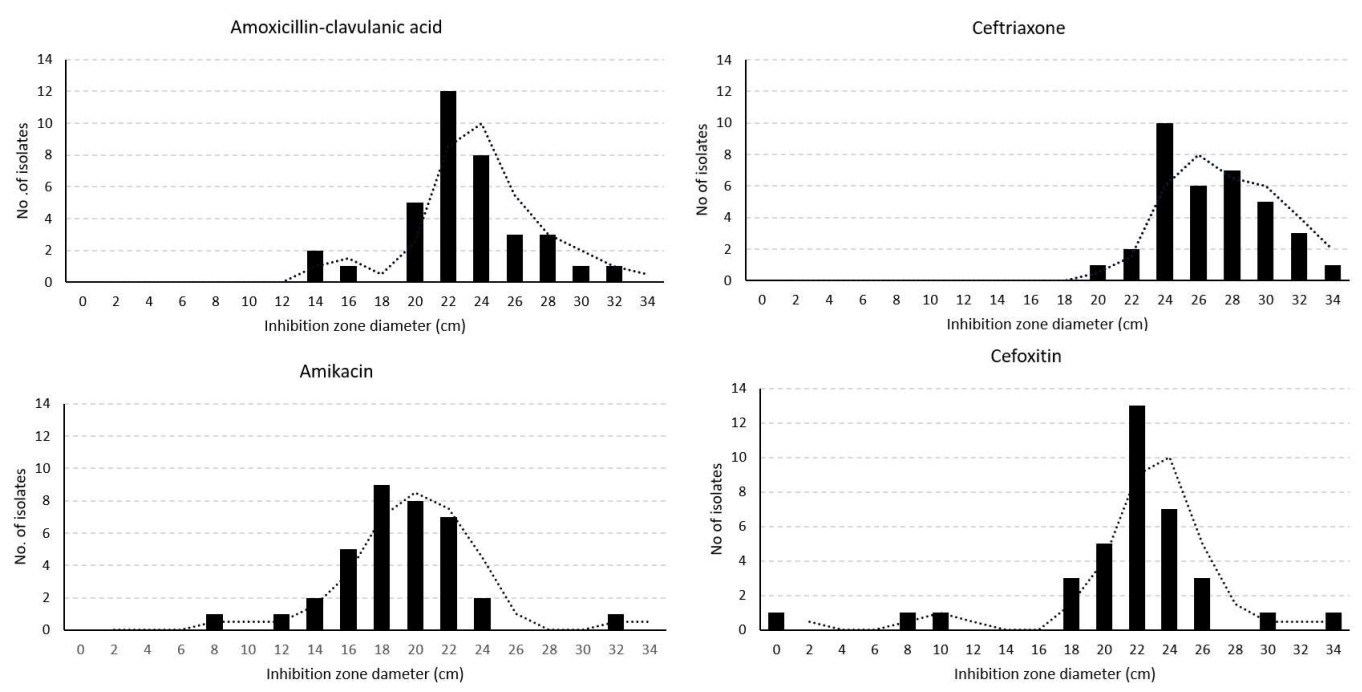

Fig 1 The distribution of inhibition zone diameter (IZD, $\mathrm{cm})$ of bacterial isolates from Sunda porcupine for four antimicrobial tested.

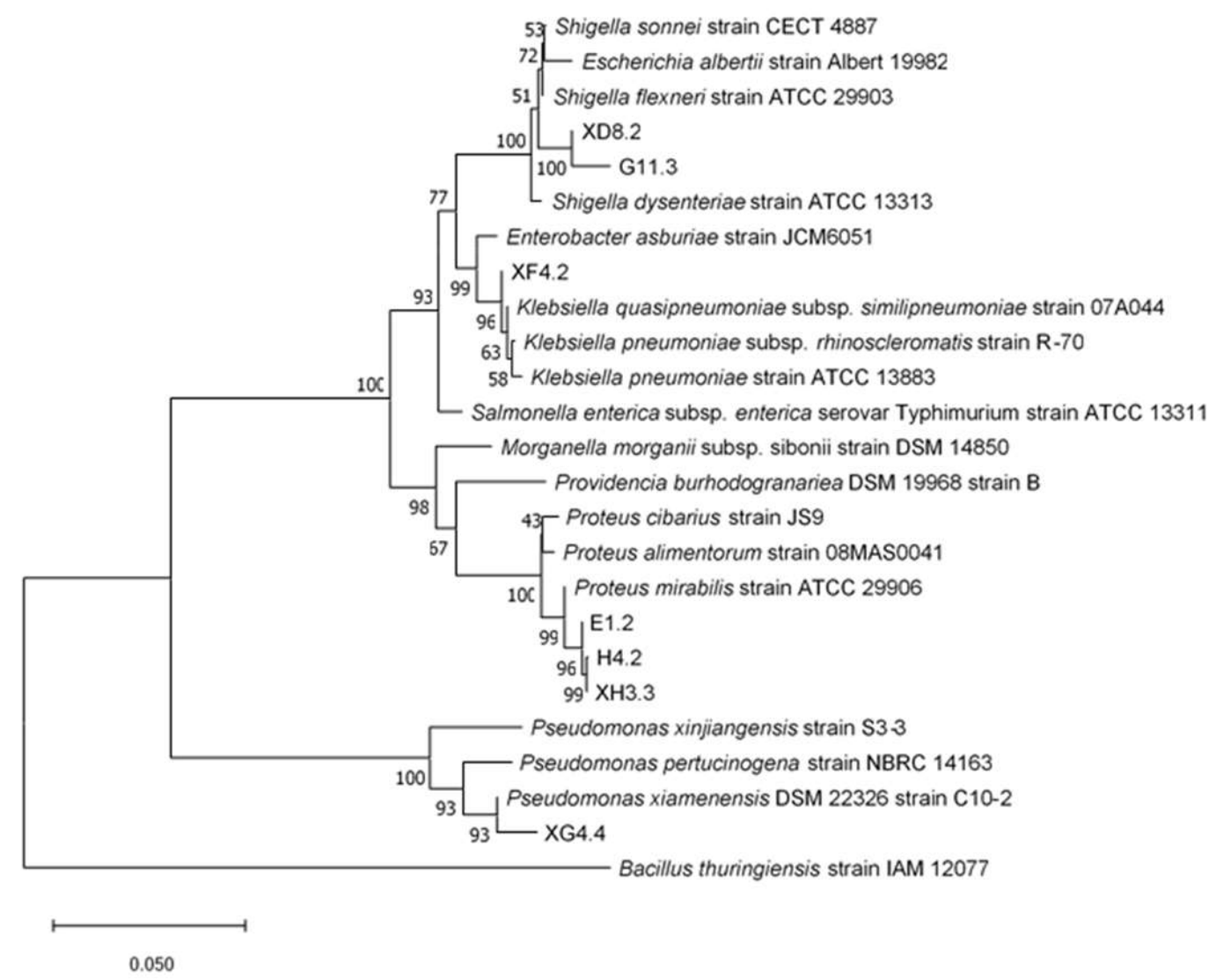

Fig 2 Phylogenetic tree construction from isolates XG4.4, XD8.2, XH3.3, XF4.2, H4.2, E1.2, and G11.3, was carried out using the neighbor joining method with 1000 bootsrap value.

2012), while Listeria was observed in Indian porcupine (Hystrix indicus) (Sarangi and Panda 2013). Based on our study, it can be assumed that Sunda porcupine has the potential as a natural reservoir for Salmonella. Percival and Williams (2014) states that natural reservoir of Salmonella is very diverse, including farm animals, domesticated animals and wild animals, including poultry, pigs, cattle, birds, dogs, rodents, turtles and cats. Consumption of contaminated poultry and meat products is the most common source of transmission. Meanwhile, the Listeria presumptive test showed positive results for all samples, showing that Listeria may presence in Sunda porcupine faecal samples. Salmonella and Listeria are among common 
Table 2 Bacterial identity and antimicrobial susceptibility testing results from seven bacterial isolates

\begin{tabular}{|c|c|c|c|c|c|c|c|c|}
\hline \multirow{2}{*}{$\begin{array}{l}\text { Isolate } \\
\text { code }\end{array}$} & \multirow[t]{2}{*}{ Species } & \multirow{2}{*}{$\begin{array}{c}\text { Identity } \\
(\%)\end{array}$} & \multirow[t]{2}{*}{ Accession } & \multicolumn{4}{|c|}{ Inhibition Zone Diameter (mm) } & \multirow{2}{*}{$\begin{array}{l}\text { Potential zoonotic } \\
\text { pathogens status }\end{array}$} \\
\hline & & & & $\mathrm{AMC}$ & FOX & CRO & $\mathrm{AK}$ & \\
\hline XH3.3 & Proteus mirabilis & 99.87 & NR_113344.1 & 24,44 & 24,44 & 31,79 & 18,83 & Yes, commonly detected \\
\hline H4.2 & Proteus mirabilis & 99.87 & NR_113344.1 & 22,76 & 22,63 & 28,88 & 18,35 & in broiler chicken \\
\hline E1.2 & Proteus mirabilis & 99.88 & NR_113344.1 & 26,86 & 25,02 & 27,51 & 22,31 & (Jamaluddin et al. 2018) \\
\hline G11.3 & Shigella flexneri & 99.98 & NR_026331.1 & 20,73 & 21,31 & 27,04 & 19,11 & Yes, causing foodborne \\
\hline XD8.2 & Shigella flexneri & 100 & NR_026331.1 & 20,14 & $7,82 *$ & 29,12 & 20,89 & diseases (Bintsis 2017) \\
\hline XF4.2 & $\begin{array}{l}\text { Klebsiella } \\
\text { quasipneumoniae } \\
\text { subsp. } \\
\text { similipneumoniae }\end{array}$ & 99.77 & NR_134063.1 & 23,28 & 22,84 & 28,12 & 21,21 & $\begin{array}{l}\text { Yes, detected in food } \\
\text { animals with other } \\
\text { Klebsiella species } \\
\text { (Davis and Price 2016) }\end{array}$ \\
\hline XG4.4 & $\begin{array}{l}\text { Pseudomonas } \\
\text { xiamenensis }\end{array}$ & 99.79 & NR_043533.1 & 30,65 & 24,52 & 35,82 & 31,29 & $\begin{array}{l}\text { Unknown, regarded as } \\
\text { denitrifying bacterium } \\
\text { isolated from activated } \\
\text { sludge (Lai and Shao } \\
\text { 2008) }\end{array}$ \\
\hline
\end{tabular}

Note: AK amikacin, AMC amoxicillin-clavulanic acid, FOX cefoxitin, CRO ceftriaxone.

* Resistance to AK, AMC, FOX and CRO was not detected. Only XD8.2 that considered as cefoxitin resistant.

cause of foodborne zoonotic diseases, as reported by European Food Safety Authority (EFSA 2020).

Three species of pathogenic bacteria were identified, including P. mirabilis (XH3.3, H4.2, and E1.2), S. flexneri (XD8.2 and G11.3) and $K$. quasipneumoniae subsp. similipneumoniae (XF4.2), while the status of potential pathogens of another identified isolates (Pseudomonas xiamenensis XG.4.4) was unknown (Lai and Shao 2008). Evidence from other studies regarding zoonotic potentials of these bacteria were presented in Table 2. One of the most cases of infection in humans are caused by Proteus mirabilis (Jacobsen and Shirtliff 2011). According to Nemati (2013), P. mirabilis is pathogenic in humans because it can cause urinary tract infections. The pathogenicity of $P$. mirabilis is supported by its unique virulence factors, such as adhesin, flagella, toxins, quorum-sensing, enzymes, and immune invasion. Together with other Shigella species such as $S$. dysenteriae, S. boydii and S. sonnei, S. flexneri are responsible for diarrheal diseases and dysentery occurring globally and may be associated with lifethreatening complications (Niyogi 2005). The spread of Shigella can occur by the faecal-oral route, where infected animals excrete Shigella along with their feces, then pollute the environment (Said and Marsidi 2017). Several Klebsiella strains according to Simmons and Gibson (2012) have been known to be pathogenic and capable of causing infection in humans, this include $K$. quasipneumoniae subsp. similipneumoniae that cause infections in human and dogs (Brisse et al. 2014). Klebsiella spp. is an opportunistic pathogenic bacterium from the Enterobacteriaceae family that can cause respiratory infections, urinary tract infections and nosocomial infections and are commonly found as microflora in the mouth, skin, intestines of humans and animals (Brisse et al. 2006, Paran et al. 2019).

Based on antimicrobial susceptibility testing and interpretation according to EUCAST and CLSI, resistance to ceftriaxone was not detected in all 36 isolates while resistance to AMC, FOX and AK was detected in seven isolates. Multidrug-resistant bacteria were not observed. This result indicates that antimicrobial resistance may not disseminate in Sunda porcupine, although accumulated evidence has revealed the presence of antimicrobial resistance in wildlife due to contaminated environment (Allen et al. 2010). Resistance to third generation cephalosporins is a major concern globally, mainly conferred by extended-spectrum b-lactamases (ESBLs) which commonly found in birds, mammals, livestock, and companion animals(Vittecoq et al. 2016).

This study has several limitations. The method used was based on culture dependent method which only showing presumptive results for Salmonella and Listeria. We were also unable to recover those bacteria due to having issues with purification, preservation, and the complexity of nutrient requirements, especially for Listeria. Further, Salmonella detection on XLD agar after enrichment step may give false positive results because the growth of Proteus bacteria in the 
medium was resemble to Salmonella colonies. Additionally, not all collected isolates were identified, therefore, the diversity of culturable faecal bacteria from Sunda porcupine was not fully understood.

Based on presumptive test results and bacterial culture, we strengthen the hypothesis that the Sunda porcupine has the potential as a reservoir of zoonotic bacteria. Several identified isolates reveal that they may be regarded as foodborne zoonotic pathogens, including from genus Proteus, Klebsiella, and Shigella. Due to low exposure to antimicrobials Sunda porcupine in this study may not play as an important host for antimicrobial resistance. Further research is needed such as identification of all collected bacteria and confirmation test for their pathogenicity. Detection of virulence genes and resistance genes can be combined to complement the detection results through a culture dependent method so that risk factors for the spread of zoonotic diseases can be understood more comprehensively.

\section{ACKNOWLEDGMENT}

This research was supported by DIPA Research Center for Biology 2018 and DIPA Research Center for Biotechnology 2019, Indonesian Institute of Science (LIPI).

\section{AUTHOR CONTRIBUTIONS}

The contribution of each author in this article is SS as the main contributor who is responsible for the formulation and overall research objectives. SAN, RANS and NI contributed to laboratory investigations and collected the data. SAN, AN and SS contributed to analyzed the data. SAN, SP, RSF, ASA, TPN and SS were responsible for original draft writing, and SAN and SS contributed to reviewing and editing the manuscript.

\section{REFERENCES}

Allen HK, Donato J, Wang HH, Cloud-Hansen KA, Davies J and Handelsman J. 2010. Call of the wild: Antibiotic resistance genes in natural environments. Nat Rev Microbiol, 8(4), pp. 251-259. doi: 10.1038/nrmicro2312.

Bachand N, Ravel A, Onanga R, Arsenault J, Gonzalez JP. 2012. Public health significance of zoonotic bacterial pathogens from bushmeat sold in urban markets of
Gabon, Central Africa J Wildl Dis 48(3):785-9.doi: 10.7589/0090-3558-48.3.785

Bintsis T. 2017. Foodborne pathogens. AIMS Microbiol. 2017 ; $3(3)$ : $529-563$. d o i : 10.3934/microbiol.2017.3.529

Brisse S, Grimont F. and Grimont PAD. 2006. The Genus Klebsiella, in. In: Dworkin M., Falkow S., Rosenberg E., Schleifer KH., Stackebrandt E. (eds) The Prokaryotes. Springer, New York, NY. https://doi.org/10.1007/0-387-30746-X_8

Brisse $\mathrm{S}$ and Passet V. and Grimont PAD. 2014. Description of Klebsiella quasipneumoniae sp. nov., isolated from human infections, with two subspecies, Klebsiella quasipneumoniae subsp. quasipneumoniae subsp. nov. and Klebsiella quasipneumoniae subsp. similipneumoniae subsp. nov., and demonstration that Klebsiella singaporensis is a junior heterotypic synonym of Klebsiella variicola. Int J Syst and Evol Microbiol, 64 (June), pp. 3146-3152. doi: 10.1099/ijs.0.062737-0.

Broad S. 2020. Wildlife trade, COVID-19 and zoonotic disease risks: shaping the response. TRAFFIC. https://www.traffic.org/publications/reports/wildlifetrade-covid-19-and-zoonotic-disease-risks-shapingthe-response/

CLSI. Performance standards for antimicrobial disk and dilution susceptibility tests for bacteria isolated from animals- 3rd Edition, VET01S. Wayne, PA, USA: CLSI; 2015.

Davis GS and Price LB. 2016. Recent Research Examining Links Among Klebsiella pneumoniae from Food, Food Animals, and Human Extraintestinal Infections. Curr Environ Health Rep. 3, pp 128-135.

Drews SJ, Lau C, Andersen M, Ferrato C, Simmonds K, Stafford L, Fisher B, Everett D and Louie M. 2010. Laboratory based surveillance of travel-related Shigella sonnei and Shigella flexneri in Alberta from 2002 to 2007. Glob Health. 6, pp1-6. doi: 10.1186/1744-8603-6-20.

EFSA (European Food Safety Authority). 2020. Foodborne zoonotic diseases. Available at https://www.efsa.europa.eu/en/topics/topic/foodborne -zoonotic-diseases.

Engel K and Ziegler S.2020. Pandora's box: A report on the human zoonotic disease risk in Southeast Asia with a focus on wildlife markets. WWF Deutschland, Berlin.

EUCAST (European Committee on Antimicrobial Susceptibility Testing). 2020. Antimicrobial Susceptibility Testing Versi 8.0. Available at: www.eucast.org

Farida WR. 2007. Kemampuan cerna dan konsumsi pakan pada landak raya (Hystrix brachyura) di Penangkaran. Laporan Teknik 2007. Pusat Penelitian Biologi LIPI. 
Farida WR. 2015. Diversitas tumbuhan pakan, habitat dan pemanfaatan landak (Hystrix sp.) di Sumatera Selatan dan Kalimantan Timur. Pros Sem Nas Masy Biodiv Indon. doi: 10.13057/psnmbi/m010348.

Fatiqin A, Novita R and Apriani I. 2019. Pengujian Salmonella dengan menggunakan media SSA dan E. coli menggunakan media EMBA pada bahan pangan. Indobiosains, 1 ( 1), pp. 22-29. doi: 10.31851/indobiosains.v1i1.2206.

Friant S, Paige SB, Goldberg TL. 2015. Drivers of Bushmeat Hunting and Perceptions of Zoonoses in Nigerian Hunting Communities. PLOS Negl Trop Dis. https://doi.org/10.1371/journal.pntd.0003792

Inayah N. 2016. Potensi pengembangan landak (Hystrix javanica) sebagai produk komersial. Fauna Indonesia, 15(2), pp. 37-43.

Jacobsen SM, and Shirtliff ME. 2011. Proteus mirabilis biofilms and catheter-associated urinary tract infections. Virul, 2(5), pp. 460-465. doi: 10.4161/viru.2.5.17783.

Jamaluddin WA, Muslimin and Djide MN. 2016. Detection of Proteus mirabilisas foodborne disease bacteria in carcass of broiler chickens (Gallus domesticus). J Indones Vet Res. 2(1) pp35-40.

Kartika D, Rahmawati and Rousdy DW. 2017. Studi analisis perilaku mencuci tangan terhadap kepadatan koloni bakteri sebelum dan setelah mencuci tangan pada mahasiswa. Protobiont, 6(2), pp. 1-7. Available at: http://jurnal.untan.ac.id/index.php/jprb/article/view/1 9494.

Lai Q and Shao Z. 2008. Pseudomonas xiamenensis sp. nov., a denitrifying bacterium isolated from activated sludge. Int J Syst Evol Microbiol. 58(8), pp. 1911-1915. doi: 10.1099/ijs.0.65459-0

Lunde D. and Aplin K. 2008. Hystrix javanica. The IUCN red list of threatened spesies. Version 2014.3. Available at: www.iucnredlist.org.

Myers P. Espinosa R, Parr CS, Jones T, Hammond GS, and Dewey TA. 2017. Hystrix javanica, The Animal Diversity. Available at: http://animaldiversity.org.

Nemati M. 2013. Antimicrobial resistance of Proteus isolates from poultry, Eur $\mathrm{J}$ Exper Biol, 3(6), pp. $499-500 . \quad$ A v a i 1 a b 1 e a t : http://hrcak.srce.hr/index.php?show=clanak\&id_clana k_jezik=50335\%0A http://www.mdpi.com/20796382/5/4/37\%0Ahttp://www.nepjol.info/index.php/IJ ASBT/article/view/17616.

Niyogi SK. 2005. Shigellosis. J Microbiol, 43, pp. 133-143.
Percival S. and Williams D. 2014. Salmonella. In: Percival SL, Yates MV, Williams DW, Chalmers RM, Gray NF (eds) Microbiology of waterborne diseases, 2nd edn', Academic Press, London, pp. 209-222.

Plotkin M. 2020. Coronavirus and Conservation: Preventing the Next Pandemic, Los Angeles Review of Books. Available at: https://lareviewofbooks.org/shorttakes/coronavirus-and-conservation/.

Prawira, AY, Novelina S, Darusman HS, Farida WR, Agungpriyono S. 2018. The dorsal skin structure contributes to the surface bacteria populations of Sunda Porcupine (Hystrix javanica. J Vet Med Series C: Anatomia Histologia Embryologia, 47(6), pp. 591-598. doi: 10.1111/ahe.12401.

Ripple WJ, Abernethy K, Betts MG, Chapron G, Dirzo R, Galetti M, Levi T, Lindsey PA, Macdonald DW, Machovina B, Newsome TM, Peres CA, Wallach AD, Wolf C, and Young H. 2016. Bushmeat hunting and extinction risk to the world's mammals. Roy Soc Op Sci, 3(10). doi: 10.1098/rsos.160498.

Said NI. and Marsidi R. 2017. Mikroorganisme patogen dan parasit di dalam air limbah domestik serta alternatif teknologi pengolahan. J Air Indones, 1(1). doi: 10.29122/jai.v1i1.2293.

Saputra S. Jordan D, Mitchell T, Wong HS, Abraham RJ, Kidsley A, Turnidge J, Trott DJ, Abraham S. 2017. Antimicrobial resistance in clinical Escherichia coli isolated from companion animals in Australia. Vet Microbiol. 211, p p. 43-50. doi : 10.1016/j.vetmic.2017.09.014.

Sarangi LN and Panda HK. 2013. Occurrence of Listeria species in different captive wild animals of Nandankanan Zoo, Baranga, Odisha, India. J Threat Tax, 5(1), p p. 3542-3547. d o i : $10.11609 /$ jott.o3175.122.

Shad AA and Shad WA. 2020. Shigella sonnei: virulence and antibiotic resistance. Arch Microbiol, (0123456789). doi: 10.1007/s00203-020-02034-3.

Vittecoq M, Godreuil S, Prugnolle F, Durand P, Brazier L, Renaud N, Arnal A, Aberkane S, Jean-Pierre H, Gauthier-Clerc M, Thomas F, Renaud F. 2016. Review: Antimicrobial resistance in wildlife, J App Ecol, 53(2), pp. 519-529. doi: 10.1111/1365-2664.12596.

Wardi, Farida WR and Siregar HCH. 2011. Tingkah laku harian landak raya (Hystrix brachyura) pada siang hari di penangkaran. Berk Pen Hay Edisi Khusus, 4 B, pp. 21-25. 